\title{
Effect of honey-flavoured diets on the performance and relative organ weights of finis her broiler chickens
}

C.O. Obun ${ }^{\mathrm{a},}$, M.S. Yahaya ${ }^{\mathrm{b}}$, O.A. Olafadehan ${ }^{\mathrm{c}}$, A.S. Kehinde ${ }^{\mathrm{a}}$, O.A. Adeyemi ${ }^{\mathrm{d}}$, I.U. Farouk $^{\mathrm{a}}$ and D.S. Allison ${ }^{\mathrm{b}}$

${ }^{a}$ Department of Animal Production Technology, Federal College of Wildlife Management, PMB 268, New Bussa, Niger State, Nigeria. ${ }^{b}$ Federal University of Technology, Yola, PMB 2076, Adamawa State, Nigeria ${ }^{\circ}$ Department of Animal Science, University of Abuja, PMB 117, Abuja, Nigeria ${ }^{\mathrm{d}}$ Department of Animal Production, Olabisi Onabanjo University, Ayetoro Campus

Abstract [0.0ㅇ Corresponding author: e-mail: obunotu@yahoo.com

A 28-day feeding trial was conducted to evaluate the effect of honey-flavoured diets on performance, nutrient retention, organ weights and economy of production. One hundred and twenty 4-weeks old 'Anak 2000' broiler chicks were randomly allotted to four treatments, replicated three times with 10 birds each in a completely randomized design (CRD). Four diets were formulated such that diet $1(0 \%)$ contained no honey and served as the control, while diets 2, 3 and 4 contained 0.5, 1.0 and 1.5\% honey-flavour, respectively. The results showed that diet 4 containing $1.5 \%$ honey flavour significantly $(P<0.05)$ improved the final body weight (1977g), weight gain (1327g), daily weight gain (47.29), feed/gain (2.18) and protein efficiency ratio (2.16) than broiler fed other diets including the control. Broilers on the control diet had the least values of body weight gain (1754g), weight gain (1104g), daily weight gain (39.43g), worst feed/gain (2.59) and protein efficiency ratio (1.80). Broilers fed diet 4 had the highest $(P<0.05)$ nutrient retention of protein $(83.80 \%)$, ether extract $(86.80$ $\%)$ and crude fibre $(70.50 \%)$ while broilers on the control diet had the lowest retention values of protein $(65.20 \%)$, crude fibre $(63.30 \%)$ and ether extract $(73.70 \%)$. The dry matter retentions were similar across the treatments with highest numerical values of $82.80 \%$ recorded by birds on diet 4 and least value of $78.80 \%$ on diet 1 (control). The liver, heart, lungs, kidney and caecum weights did not differ significantly $(P>0.05)$ across the treatments but were numerically higher with increased in the honey-flavoured diets. The gizzard and caecum weights were significantly $(P<0.05)$ increased with increase in honey flavoured diets. Cost per $\mathrm{kg}$ feed increased as the level of honey-flavoured inclusion in the diets increased $1.5 \%$ with value of $58.00 / \mathrm{kg}$ compared to the control diet with $47.01 / \mathrm{kg}$ while the revenue generated showed that birds fed diet 4 (1.5\% honey) were the most economical to produce with value of $\$ 597.15 /$ bird compared with those on the control ( $496.80 /$ bird). Addition of honey at $1.5 \%$ demonstrated superiority in this study with no adverse effect on bird's performance and organ.

Keywords: honey, additive, supplementation, broiler, performance, organ

\section{Introduction}

The introduction of feed additive to livestock feed has led to several researches by different authors (Iyayi and Bashar, 1998; Abubakar et al., 2004) using different types of feed additives for
Improving the performance of broiler chickens.

Today, the use of gut flora modulators such as prebiotics, probiotics and organic acids in farm animal feeding as an 
alternative to antibiotics are on the increase due to the restriction on the use of prophylactic doses of antibiotics as growth promoters in livestock diets preparation. Prebiotics and probiotics has been described as feed components that benefit the host by selectively accelerating growth rate and/or proliferation of one or more of a limited number of bacteria that colonize chicks intestine (e.g. Escherichia coli, Clostridium perfringes etc) to enhance digestibility (Simon, 1995; Mandal et al., 2004). Prebiotics like galactooligosaccharide (GOS), fructooligosaccharide (FOS), mannanoligosaccharide (MOS) and lactose derivatives have been tried in chickens and other monogastric animals to combat colonization of pathogens and to serve the function of anti-biotic feed additives which are banned in certain countries due to public health hazard (Mandal et al., 2004). To avoid the risk in the use of antibiotic as growth promoters, the discovery and use of prebiotics and probiotics having no withdrawal time and no residual effect have become necessary. One of such prebiotics additive is honey. Honey is a natural product which bees collect from nectar of a wide variety of plants that is concentrated by evaporation of water to form a saturated or super saturated solution of sugar consisting typically of $17 \%$ water, $38 \%$ fructose, $31 \%$ glucose, $10 \%$ other sugar such as FOS and a wide range of micro-nutrients, vitamins, minerals and amino acids, with a pH below 4 (White et.al, 1975; Hara et al., 1998; Chow, 2002).

Available literature reported that the use of honey has some beneficial effects in human diet (Abuharfeil et al., 1999) and in rats diets (Busserolles et al., 2002). Honey improves palatability of feed, serve as feed binder, improves the nutritive value, growth rate, digestibility and feed efficiency of livestock (Ebisu et al., 1988; Busserolles et al., 2002), prevents intestinal infection, influences proliferation of micro-flora in rat's guts and leads to improvements in the general health and lipid metabolism (Shamala et al., 2000; Busserolles et al., 2002; Adebolu, 2005). Honey has also been reported to have therapeutic effects in human ailments (Okeniyi, 2005; Orsolic et al., 2005), act as an anti-oxidant against feed rancidity (Frankel et al., 1998) and possesses anti-microbial properties (Adebolu, 2005). However, pure honey have been reported to contain phytochemical such as alkaloids, anthraquinone glycosides, cardiac glycosides, flavoids, saponins, tannins and phenolic compounds which can act as antioxidants (Agbaje et al., 2006).. From the foregoing, this study is aimed at evaluating the effect of honey addition in diets of broiler chicks' on performance, nutrient utilization, nutrient retention and organs weights.

\section{Materials and Methods}

Study area

The experiment was conducted at the Poultry unit of the Federal College of Wildlife Management, New Bussa, Niger State, Nigeria.

\section{Diet formulation}

Pure undiluted honey was purchased from a commercial farmer in New Bussa, Niger State, Nigeria. Honey being a viscous matter, homogenization of the diets was a problem. However, viscosity of the honey was lowered by raising the temperature $\left(20^{\circ} \mathrm{C}\right)$ of honey by slowly heating in flame in a short duration (10 minutes) not to destroy bacteria and impair off flavour and volatile aroma but to lower the viscosity for easy mixing in feed (White et. al, 1975). Four iso-nitrogenous and 
iso-caloric diets were formulated such that diet 1 had no honey (control) while diets 2,3 and 4 contained $0.5,1.0$ and $1.5 \%$ honey addition, respectively. These levels were chosen based on available literature on significant influence of small quantities and the therapeutics effects in human meals and in animals feed (Busserolles et al., 2002; Ekanem et al., 2006).

Management of experimental birds

One hundred and twenty (120) 4 weeksold Anak broiler chicks' were randomly allotted to four treatment groups. Each treatment was replicated three times with 10 birds each in a completely randomized design. The birds were raised in floor pens $(1.20 \mathrm{~m} \times 1.30 \mathrm{~m})$ for 4 weeks. The diets and water were provided ad libitum. All the birds were reared under natural tropical conditions $\left(29-33^{\circ} \mathrm{C}, 80-100 \%\right.$ relative humidity throughout the 28 days period of study). All management practices applicable to broilers were adhered to strictly. Records of daily feed intake and weekly weight gain were taken from which feed conversion and protein efficiency ratios were calculated. Mortality was also observed and recorded daily.

\section{Nutrient retentions trial}

On the $28^{\text {th }}$ day of the experimental period, three broilers per replicate were transferred to metabolic cages, fed ad libitum and allowed adjustment to the cages environment for four days. Excreta were collected for five days, oven dried to constant weight and pooled for proximate [Dry Matter (DM), Crude Protein (CP), Crude Fibre (CF) and Ether Extract (EE)] analysis. Nutrient retention was determined according to Aduku (2004) methods.

Organ weights and feed cost determination

Three birds were selected from each replicate group, fasted over night and slaughtered. The organ weights (liver, heart, kidney, lungs, gizzard and caecum) were neatly removed and weighed. These organs were studied due to their sensitivity to toxin reaction and microbial influence activities in caecum size. Feed cost/ $\mathrm{kg}$ diet and cost of production per bird was calculated by summing up total cost of all the ingredients that constituted the diets.

\section{Chemical assay}

The honey, experimental diets and excreta were analyzed for crude protein, ether extract, crude fibre, ash and nitrogen free extract using AOAC (1990) methods.

Statistical analysis

All data obtained were subjected to statistical Analysis of Variance as described by Steel and Torrie (1980) at $5 \%$ probability test using SPSS 13.00 software. Significantly different means were compared using Duncan's Multiple Range Test (Duncan, 1955).

\section{Results}

The results of the effect of honeyflavoured diets on average final body weight (AFW), body weight gain

(BWG), daily weight gain(DWG), feed intake (FI), feed conversion ratio (FCR), protein efficiency ratio (PER) and mortality of finisher broilers are presented in Table 2. Significant differences $(\mathrm{P}<0.05)$ were shown in AFW, BWG and DWG due to varying levels of honey-flavoured diets. The highest AFW of $1977 \mathrm{~g}$ was observed in birds on $1.5 \%$ honey-flavoured diet, which had the highest BWG of $1327 \mathrm{~g}$ and DWG of $47.29 \mathrm{~g}$. The birds on diet 1 (control) had the least AFW of 1754, BWG of 1104 and DWG of $39.43 \mathrm{~g}$. 
Table 1 . Composition (\%) of the experimental diets

\begin{tabular}{|c|c|c|c|c|c|}
\hline \multirow[b]{2}{*}{ Parameters } & & \multicolumn{4}{|c|}{ Diets } \\
\hline & & $\mathbf{1}$ & 2 & 3 & 4 \\
\hline Maize & & 37.40 & 37.40 & 37.40 & 36.90 \\
\hline Maize offal & & 25.00 & 24.50 & 24.00 & 24.00 \\
\hline GNC & & 27.60 & 27.60 & 27.60 & 27.60 \\
\hline Fish meal & & 4.50 & 4.50 & 4.50 & 4.50 \\
\hline Blood meal & & 1.50 & 1.50 & 1.50 & 1.50 \\
\hline Honey & & - & 0.50 & 1.00 & 1.50 \\
\hline Bone meal & & 3.00 & 3.00 & 3.00 & 3.00 \\
\hline Lysine & & 0.25 & 0.25 & 0.25 & 0.25 \\
\hline Methionine & & 0.25 & 0.25 & 0.25 & 0.25 \\
\hline *Premix & & 0.25 & 0.25 & 0.25 & 0.25 \\
\hline Salt & & 0.25 & 0.25 & 0.25 & 0.25 \\
\hline Total & & 100.00 & 100.00 & 100.00 & 100.00 \\
\hline \multicolumn{6}{|c|}{ Determined Analysis } \\
\hline & Honey & & & & \\
\hline Dry matter $(\%)$ & 88.08 & 95.50 & 95.30 & 94.80 & 93.40 \\
\hline Crude protein $(\%)$ & 3.44 & 19.26 & 19.20 & 19.24 & 19.22 \\
\hline Ether extract (\%) & 9.34 & 4.60 & 5.01 & 4.90 & 4.90 \\
\hline Crude fibre (\%) & 0.02 & 4.90 & 4.70 & 4.60 & 4.70 \\
\hline $\mathrm{ME}(\mathrm{MJ} / \mathrm{kg})$ & 12.60 & 12.96 & 12.96 & 12.97 & 12.97 \\
\hline
\end{tabular}

*To provide the following per $\mathrm{kg}$ diet: Vit A. 15, 000, $000 \mathrm{iu}$, Vit D $\begin{array}{lll}\text { OOO iu, Thiamine, } & -, 2000 \mathrm{mg} \text {, Vit. K. 2500mg, Riboflavin - 6000mg, Pyridoxine - 4000mg, Niacin } \\ 40 \text {, O00mg, Vit. B } & 12 \text { 20mg, Penthothenic ac id 10,000mg, Folic acid,1000mg, Biotin 80mg, }\end{array}$

Choline chloride 500g, antioxidant 125g, Mn. 96g, Zn 60mg, Fe 24g, Cu 6g, Iodine 1.4g, Se $240 \mathrm{mg}$, cobalt $120 \mathrm{~g}$.

The total feed intake significantly $(\mathrm{P}<0.05)$ differed among the broilers. Birds on diet 3 had the highest feed consumption of $2934 \mathrm{~g}$ as against the control birds with the least value of $2862 \mathrm{~g}$. The daily FI was similar $(\mathrm{P}>0.05)$ among the birds with a similar trend as the total FI.

The FCR and PER of birds on the control diet were significantly $(\mathrm{P}<0.05)$ different when compared with those on honeyflavoured diets. The FCR and PER of birds on diets 2 and 3 were similar $(\mathrm{P}>0.05)$ but significantly $(\mathrm{P}<0.05)$ different from those on diets 1 and 4 . The best FCR and PER were recorded by birds on diet 4 (1.5\% honey-flavoured) with values of 2.18 and 12.16 , respectively as against the control with 2.59 and 1.80 , respectively.

Table 2: Performance, economy of production and nutrient retention of experimental birds

Parameters

Initial body weight ( $\mathrm{g} / \mathrm{bird})$

Final body w eight/bird $(\mathrm{g})$

Body weight gain/bird (g)

Daily weight gain $(\mathrm{g})$

Total feed consumed/bird (g)

Daily feed in take $(\mathrm{g})$

Feed conversion ratio (FCR)

Prote in efficiency ratio (PER)

Mortality (\%)

Cost of feed/ Kg diet (?)

Total cost of feed consumed/bird ((?)

Cost of feed /Kg weight gain (?)

Revenue generated/bird

(? 450/kg live weight gain)

Nutrient retention $(\%$

Dry matter

E ther ex tract

Crude protein

Crude fibre

Ceans with different supersc

SEM : Standard error of mean

\begin{tabular}{|c|c|c|c|c|}
\hline \multicolumn{5}{|c|}{ Dietary Treatment } \\
\hline 1 & 2 & 3 & 4 & S EM \\
\hline 650.00 & 651.00 & 647.00 & 650.00 & 0.73 \\
\hline $1754.00^{\mathrm{d}}$ & $1840.00^{\mathrm{c}}$ & $1861.00^{\mathrm{b}}$ & $1977.00^{\mathrm{a}}$ & 53.00 \\
\hline $1104.00^{\mathrm{d}}$ & $1189.00^{\mathrm{c}}$ & $1214.00^{\mathrm{b}}$ & $1327.00^{\mathrm{a}}$ & 52.34 \\
\hline $39.43^{\mathrm{c}}$ & $42.46^{\mathrm{b}}$ & $43.36^{\mathrm{b}}$ & $47.29^{\mathrm{a}}$ & 1.08 \\
\hline $2862.00^{\mathrm{d}}$ & $2907.00^{\mathrm{b}}$ & $2934.00^{\mathrm{a}}$ & $2892.00^{\mathrm{c}}$ & 17.36 \\
\hline 102.21 & 103.82 & 104.79 & 103.29 & 0.21 \\
\hline $2.59^{\mathrm{a}}$ & $2.45^{\mathrm{b}}$ & $2.42^{\mathrm{b}}$ & $2.18^{\mathrm{c}}$ & 0.35 \\
\hline $1.80^{\mathrm{c}}$ & $1.93^{\mathrm{b}}$ & $1.95^{\mathrm{b}}$ & $2.16^{\mathrm{a}}$ & 0.12 \\
\hline 0.30 & 0.30 & 0.00 & 0.30 & 0.002 \\
\hline 47.01 & 50.00 & 54.00 & 58.00 & 0.61 \\
\hline $134.54^{\mathrm{d}}$ & $145.35^{\mathrm{c}}$ & $158.44^{\mathrm{b}}$ & $167.74^{\mathrm{a}}$ & 0.04 \\
\hline 121.87 & 122.25 & 130.51 & 126.41 & 1.01 \\
\hline $496.80^{\mathrm{d}}$ & $535.05^{\mathrm{c}}$ & $546.30^{\mathrm{b}}$ & $597.15^{\mathrm{a}}$ & 1.54 \\
\hline 78.50 & 78.80 & 81.00 & 82.80 & 0.97 \\
\hline $73.70^{\mathrm{c}}$ & $75.50^{\mathrm{bc}}$ & $77.80^{\mathrm{b}}$ & $86.80^{\mathrm{a}}$ & 0.053 \\
\hline $65.20^{\mathrm{d}}$ & $70.20^{\mathrm{c}}$ & $77.40^{\mathrm{b}}$ & $83.80^{\mathrm{a}}$ & 0.15 \\
\hline $63.30^{\mathrm{b}}$ & $64.70^{\mathrm{ab}}$ & $67.00^{\mathrm{a}}$ & $70.50^{\mathrm{a}}$ & 0.06 \\
\hline
\end{tabular}

significan tly different $\quad(\mathrm{P}<0.05)$ 
Percentage mortality was not significantly $(\mathrm{P}>0.05)$ influenced by the treatments. Birds on diet 3 had no mortality while the rest treatment had the same percentage mortality of $0.3 \%$ each. Dietary honey flavoured diets significantly $(\mathrm{P}<0.05)$ improved all the nutrient retention values but had no discernible effect $(\mathrm{P}>0.05)$ on the dry matter retention. Nutrient retention of fat, crude protein and crude fibre were highest $(\mathrm{P}<0.05)$ at $1.5 \%$ honeyflavoured diet with values of $86.80,83.80$ and $70.50 \%$ while the least values of fat (73.70\%), CP (65.20\%) and CF (63.30\%) were recorded by birds on the diet 1(control).

There was no significant $(\mathrm{P}>0.05)$ difference across the various diets in feed cost/ $\mathrm{kg}$ diets and feed cost/ $\mathrm{kg}$ live weight. The lowest feed cost $/ \mathrm{kg}$ and feed cost $/ \mathrm{kg}$ live weight was diet 1 with ? 47.01 and ? 121.87 while the highest was diet 4 with ? 58.00 and ? 126.4. The cost of feed consumed per broiler and revenue generated from birds on $1.5 \%$ honey-flavoured diets were significantly $(\mathrm{P}<0.05)$ higher with values of ? 167.74 and ? 597.15 compared to broilers on diet 1 with? 134.54 and ? 496.80.

The relative weights of the gizzard and caeca were significantly $(\mathrm{P}<0.05)$ different among the treatments in this order: $0<5<10<15 \mathrm{~g} / \mathrm{kg}$ honey supplementation (Table 3 ). However, the relative weights of the liver, heart, lungs and kidney of the birds were not significantly $(\mathrm{P}>0.05)$ influenced by dietary honey supplementation, though higher numerical values were recorded with increasing levels of honey in the diets.

Table 3: Live weight, dressing percentage and related organ weights of finisher broiler chickens.

\begin{tabular}{lllllll}
\hline & \multicolumn{5}{c}{ Dietary Treatment } \\
\cline { 2 - 7 } Parameters & $\mathbf{1}$ & $\mathbf{2}$ & $\mathbf{3}$ & $\mathbf{4}$ & SEM \\
\hline $\begin{array}{l}\text { Liveweight } \\
\text { Organ }\end{array}$ & $\mathbf{( g / b i r d )}$ & $1754.00^{\mathrm{d}}$ & $1840.00^{\mathrm{c}}$ & $1861.00^{\mathrm{b}}$ & $1977.00^{\mathrm{a}}$ & 53.00 \\
Liver & & & & & \\
Heart & 1.71 & 1.74 & 1.76 & 1.78 & 0.27 \\
Lung & 0.52 & 0.54 & 0.54 & 0.56 & 0.73 \\
Gizzard & 0.56 & 0.58 & 0.58 & 0.61 & 0.91 \\
Kidney & $1.79^{\mathrm{c}}$ & $1.81^{\mathrm{c}}$ & $1.86^{\mathrm{b}}$ & $1.98^{\mathrm{a}}$ & 0.02 \\
Caeca & $0.45^{\mathrm{c}}$ & $0.46^{\mathrm{b}}$ & 0.48 & 0.48 & 1.01 \\
\hline abcd Means on the same row with different superscript are significantly $(\mathrm{P}<0.05)$ & $0.72 \mathrm{a}$ & 0.05 \\
different. & $0.54^{\mathrm{c}}$ & $0.59^{\mathrm{b}}$ & $0.64^{\mathrm{b}}$ & \\
${ }^{1}$ Expressed as percentage of live weight.
\end{tabular}

\section{Discussion}

The significantly improved feed intake of birds fed honey flavoured diets compared to those on the control diet may be due to improved palatability and reduced dustiness of the feed, since honey acts as feed binder. This result agrees with the report by Sekoni (1997) that chickens tend to eat less if their ration is dusty irrespective of the energy level.
According to the author, acceptability of the feed has more influence on the feed intake than the energy level per se. This result also confirms reports by Ebisu et al. (1988) that honey is a binder and adds palatability to diet. However, the reduced feed intake of birds on $1.5 \%$ honey compared to the other honey based diets may probably be attributed to the increased breakdown of the non-starch polysaccharide (NSP) as a result of the 
microbes' proliferation in the caecum which thus increased the ME content in the diet more than the other honey supplemented diets. Honey, as a prebiotic, has been reported to increase the proliferation and also enhanced the activities if microbes in the GIT or caecum. (Gojmerac, 1981; Bursserolles et al., 2002; Agbaje et al., 2006).

The marked improved growth response, feed/gain, PER and nutrient retention by birds fed honey flavoured diets could also be attributed to this influence of microflora multiplication in the digestive tract which probably enhanced the breakdown of the dietary fibre and thus improved the digestion, absorption and utilization of essential nutrients (Moreto and Planas, 1989; Shamala et al., 2000).This was evident in the improved crude fibre retention on birds fed honey based diets.

This result confirms earlier findings (Ebisu et al., 1988; Busserolles et al., 2002) that dietary supplementation with honey improves the nutritive value, growth rate, digestibility and feed efficiency of livestock. The enhanced performance of birds on honey supplementation could also possibly be attributed to the fact that honey has been reported to contain a number of enzymes and other substances needed to breakdown the unavailable polysaccharides for the use by birds as additional energy (Mandal et al., 2004). This implies that more energy must have been made available and utilized by the birds for improved weight gain. However, it is known that nutrients, especially protein, metabolized by micro-flora are not utilized by the host. This might have stimulated proteolytic or protein digestion activity, thereby contributing to the improvement in nutrient digestion and absorption.

Further more, honey has been reported to compose primarily of fructose and glucose and about 3 to $4 \%$ FOS (Chow, 2002). Although the level of FOS in honey is low, it is not impossible that this substance with prebiotic properties may have had some metabolic effects on nutrient utilization. These carbohydrates (GOS and FOS) are not hydrolyzed in the small intestine but degraded in the caecum by intestinal micro flora (Wang and Gibson, 1993). This was evident in the significantly increased caecum size of broilers fed honey flavoured diets, especially diet 4 (1.5\% honey). These results are similar to reports by Busserolles et al. (2002) who reported improved body weight gain, nutrient utilization and increased caecum size of rats fed honey diets compared to those fed refined carbohydrates and fructose. In addition, honey has been reported to contain 181 substances (White, 1979), other carbohydrates and a variety of micronutrients (Crane, 1975; Doner, 1977) which may have enhanced birds performance, especially those on honey supplemented diets (Busserolles et al., 2002). The enhanced nutrient retention of crude fibre in the honey-flavoured diets with increased in inclusion levels could be due to the effect of honey as a prebiotic agent which aid the proliferation of microorganism in the gut of the birds, which would have fermented and broken the dietary fibre in the diets. This finding agrees with the observation by Ahmed (2006).

The reduction in feed cost $/ \mathrm{kg}$ from the control dietary birds resulted to the least cost of production per kg weight gain. The high cost of honey due to the high demand for consumption by humans and other industrial uses may have influenced the increased cost $/ \mathrm{kg}$ diet, cost of feed consumed and cost of feed $/ \mathrm{kg}$ weight gain. The result disagreed with the 
findings of Ekenyen (2002) who reported that reducing feed cost $/ \mathrm{kg}$ diet was justifiable when production results is comparable with standard control. The increase in the revenue accruing from birds on honey based diets is encouraging, since the motive of the farmer is to produce birds of desirable weight so as to maximize profit. The increased weights and revenue generated from birds on honey supplemented diets revealed a general financial increase with increasing honey in the diets.

The numerical higher relative organ weights of gizzard, liver, heart, lungs, and kidney of birds fed honey flavoured diets may probably be due to their differences in bird's live body weight, since the surface area and the live weight determine the amount of feathers and visceral organs required (Broadbent et al., 1981). Esonu et al. (2008) reported that organ weights are an index of nutrients retained by the birds. According to Butcher et al. (1983), external and internal offal percentages tend to increase as slaughter weight of animal increase. The non significant influence of honey among treatments on the liver, kidney and heart is an indication of absence of toxin in honey since hypertrophy or hypotrophy of these organs has been associated with the presence of toxin (Voss et al., 1990; Ewuola et al., 2003; Aderemi, 2003). The results confirm reports of Philip and Goodman (1999) that honey is nonirritating to the lining of digestive tract, easily and rapidly assimilated and best handled by the kidney. The increased in caecum weights with increasing honey is an indication of proliferation of microbes' activities in the GIT.

\section{Conclusion}

This study revealed that broilers fed high level $(1.5 \%)$ of honey supplementation exhibited better BWG, FCR and PER compared to the control. Honey supplementation enhanced nutrient retention and appeared to influence micro flora proliferation in the caecum which breaks down the dietary fibre to release more energy. The increased weight gain and revenue generated from birds on honey supplemented diets revealed a general financial increase with increasing honey in the diets. The organ weights were best at $1.5 \%$ honey inclusion level and were live weight dependent. The use of honey at $1.5 \%$ supplementation in this study was beneficial to the broiler chickens.

\section{References}

Abuharfeil, N., Al-Oran, R. and AboShehawa, M. 1999. The effect of bee honey on the proliferation activities of human B-and Tlymphocytes and activity of phagocytes. Food Agric. Immunol., 11:169-77.

Abubakar, A.Sekoni, A.A.,Tukur, H.M. and Hassan,W.A. 2004. Impact of yeast supplementation on the growth performance of pullet chicks fed diets with high level of Rice bran. In sustaining Livestock production under changing economic fortunes. In proceeding of the $29^{\text {th }}$ Ann. Conf. Of NSAP, In Eds of Turkur H.M. Hassan W.A. Maigandi, S.A; Pinyjothe, J.K., Daneji A.I., Balan, I.C.M and Olorede, B.R., University of Sokoto. $21^{\text {st }}-25^{\text {th }}$ March, pp. 265-267.

Adebolu, T. T. 2005. Effect of natural honey on local isolates of diarrhea causing bacteria in South Western Nigeria. Africa Biotech. 4 :11721174

Aderemi, F. A. 2003. Effect of enzyme supplemented cassava root sieviet in cassava based diet on some visceral organs of pullet chicks. In: E. A. 
Olatunji, B. A., Ayanwale, E. L. Shiawoya and A. Aremu (eds). Proceedings of the $8^{\text {th }}$ Annual Conference of Animal Science Association of Nigeria . Minna 17$24 \mathrm{pp}$

Aduku, O.A. 2004. Animal nutrition in the tropics: Feed and feeding, pasture management, monogastric and ruminant nutrition. Devon computer, Kaduna, $140 \mathrm{pp}$.

Agbaje, E.O.,Ogunsanya, $T$ and A i werioba, O. I . 2006 . Conventional use of honey as antibacterial agent. Bioline Intern. Annals of African Medicine, 5 (2):78-81

Ahmed, I. 2006. Effect of probiotics on broiler performance. International Journal of Poultry Science 5(6): 593-597.

AOAC 1990. Official Method of Analysis. Association of Official Analytical Chemist, Washington D.C.

Broadbent, J. A, Wilson, B.J. and Fisher, C. 1981. The composition of broiler chickens at 56 days of age: Output components and chemical composition. Br. Poultry Sci. 22,410

Busserolles, J., Gueux, E., Rock, E., Mazur, A. and Rayssiguier, $\mathrm{A}$. 2002. Substituting honey for refined carbohydrates protects rats from hyper tri triglycerdemic and pro oxidative effect on fructose. Journal Nutrition 132: 3379-3382pp

Butcher, C., Brynart, M.J., Owen, E. Leach, $J$ and Machin D.H. 1983. The effect of dietary metabolizable energy concentration upon the pre and post weaning performance of growing rabbits. Anim. Prod. 36:229-236.

Chow, J. 2002. Probiotics and prebiotics.
A brief review $J$. Ren Nutrition, 12: $76-86$

Crane，E. 1975. Honey a comprehensive survey; Crane Russak and Company, New York.

Doner, L.W. 1977. The sugars of honey: A Review, Journal Science Food Agric. 28: 443-456.

Duncan, D.B. 1955. Multiple Range and Multiple of Tests. Bio metrics 1:142.

Ebisu, T., Maeda, N., Matsubara, H and Kato, K. 1988. .Honey powder composition as additives for food and pharmaceuticals, Japanese $\mathrm{P}$ a t e $\mathrm{n} \mathrm{t} \quad \mathrm{N} \mathrm{o}$ 63157943(88157943),pp3

Ekanem，J,T, Majolagbe，O.R., Suileman, F.A., and Muhammad, N.O. 2006. Effect of honeysupplemented diet on the parasitemia and some enzymes of trypanosoma brucei-infected rats. African Journal of Biotechnology. 5 (17):1557-1561

Ekenyen, B.U. 2002. Economic viability of raising weaner rabbits on guinea grass(Panicum maximum) supplemented with graded levels of poultry grower ration. In Proc. of Nig. Soc. for Anim. Prod., Akure, 17-21 March,180-181pp.

Esonu, B.O, Emenelom, O.O., Maduwere, C.C. Udedibie, A.B. and Uchegbu, O.A. 2008 . Evaluation of oil palm (Elaesis guinensis) leaf meal a feed ingredient in broiler diets. Nig. $J$. Anim. Prod. 35 (1): 32-39.

Ewuola, E.O., Ogunlade, J.T., Gbore, F.A., Salako, A.O., Idahor, K.O a n d E g b u n i k e, G . N . 2003.Performance evaluation and organ histology of rabbits fed Fuserium verticilliodes culture materials. Trop.Anim Invest. 6:111- 
119

Frankel, S., Robinson, G.E and Berenbaum, F. 1998. Antioxidant capacity and correlated characteristic of 14 uniflora honeys. Apicul.Res.37:27031

Gojmerac, W.L. 1981. What you should know about honey. Eureka Valley Enterprises, Madison.

Hara, T., Cameron-Smith, D., Cooney, G.J., Kusunoki, M. ,Tsutsumi, K and Stolien, L.H. 1998. The action of a novel lipoprotein lipase activator, No.1886, in hyper triglyceridemic fructose fed rats. Metabolism 47: 149-153.

Iyayi, E.A. and Bashar, Y.A. 1998. Performance of finisher broilers fed roxazyme supplemented diet. In: Oduguwa, O.O., Fanimo, A.O. and Osinowo, O. A (Eds). Proc. of Silver Ann. Conf. of Nig. Soc. for Anim.Prod and Inaugural Conf. of W/African Soc. for Anim. Prod. 2126 March, Abeokuta, Nigeria,550551

Mandal, A.B. Yadav, A.S., Johri, T.S. and Pathak, N.N. 2004. Nutrition and disease management of poultry. International Book distribution $\mathrm{CO}$. Lucknow, India, 12-370pp.

Moreto, $M$ and Planas, J.M. 1989. Sugar and amino acid transport properties of the chickens' caeca. $J$. Exp. Anim. Zoo. 3 (Suppl.) 111-116.

Okeniyi, J.A.O. 2005. Comparison of healing of incised abscess wounds with honey and eusol dressing. $J$. Aller. Compl. Med. 11:511-513.

Orsolic, N., Erzic, S., Scarronvev, L. and Basic, I. 2005. Honey bee products in prevention and/or therapy of murrains transplantation tumors. J. Sci. Food Agric. 85:363370 .

Philip, T. and Goodman, N. 1999.
Honey and wealth control, Bubble, USA. P.90

Sekoni, A. A. 1997. Utilization of cassava peels as energy source for chickens. A Ph.D. thesis, Ahmadu Bello University, Zaria, Nigeria.

Shamala T.R., Shrijyoth, $Y$ and Saibaba, P. 2000. Stimulatory effect of honey on multiplication of lactic acid bacteria under in vitro and in vivo conditions. Lett. Appl, Microbiol. 30:453-455.

Simon, O. 1995. Micro-organism in feed additives and prebiotic. Adv. Pork Prod. 16:161-165.

Steel, R.G.D. and Torrie, J.H. 1980. Principles and procedures of statistics. A biometric approach $2^{\text {nd }}$ ed. MC Graw Hill Book CO. Inc., New York.

Wang, $X$ and Gibson G.R. 1993. Effect of in vitro fermentation of Oligofructose and Inulin by bacteria growing in the human large intestine J. Appl. Biocteriol. 75:373-380.

White, J.W.J., Riethof, M.L., Subers, M.H, and Kushmair, I. 1975. Composition of American honey, U.S. Government Printing Office, Washington, D.C.

White, J. A. (1979). Composition of honey. In: Crane (ed). Honey review, Heinemann, London 157206.

Voss, K.A., Platner, R.D., Bacon, C.W. and Norred, W.P. 1990 . Comparative study of hepatoxicity and fumonsin and B2 content of water and chloroform/methanol extracts of Fusarium moniliforme strain MRC 826 culture material, Mycopathol. 112:81-92. 